\title{
A CONSTITUTIONAL DEMOCRACY SHOULD PROVIDE FOR THE LEGALISATION OF ORGAN TRADING
}

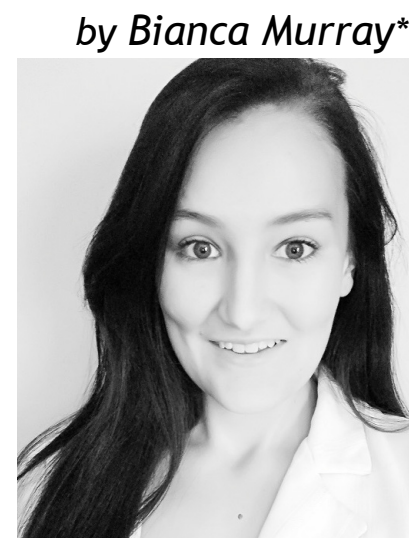

\section{Introduction}

The choice before us is not between buying or not buying organs. ${ }^{1}$ This is happening regardless of the law. The choice is whether transplant operations and the sale of organs will be regulated or not. ${ }^{2}$ It is in light of this statement that I propose a legalised system of organ trading. Desperate people will turn to the black market regardless of the law. If organ trading could be regulated, we can protect all parties involved and ensure that they get the benefit they deserve. ${ }^{3}$

A very important factor of this way of procuring organs is that it will curb the organ shortage. The waiting period for an organ transplant in South Africa is 5-11 years. Approximately $50 \%$ of people die while being on a waiting list for an organ transplant. ${ }^{4}$ While there is such a dire need for organs, research has shown that only $0.2 \%$ of

* Final year LLB student at the University of Pretoria. This article highlights the need for constructive conversation around organ trading. It speaks to the fact that regardless of the law, organ trading will continue. In this article the argument is made that when properly regulated organ trading can be successful not to mention beneficial.

1 In this article organ refers to all the solid organs, which include the kidneys, lungs, liver, pancreas and heart.

2 M Slabbert \& $\mathrm{H}$ Oosthuizen 'Establishing a market for Human organs in South Africa part 2: Shortcomings in legislation and the current system of organ procurement' (2007) Obiter at 323.

3 S Khoza 'The Human organ trade-the South African tragedy' (2009) Forum at 47.

4 Roche 'Living kidney donor education booklet'. 
South Africans are organ donors. ${ }^{5}$ Something must be done to motivate more people to become organ donors. While the need for organs grows daily, the black market is flourishing. As none of the organ procurement systems in other countries are successful enough to provide the need for organs, our only viable option might be to implement a payment system. When closely regulated, the system of organ trading can be an enormous success.

\section{South Africa's system regarding organ procurement}

\subsection{The Constitution}

The Constitution of the Republic of South Africa, 1996 (hereafter the Constitution) does not specifically make provision for organ donations or organ transplants. There are, however, certain rights contained in the Bill of Rights that can be interpreted in relation to organ transplants. Firstly, is the right to life which is set out in section 11 of the Constitution. ${ }^{6}$ Venter suggests that the right to life does not merely refer to living, but also entails the right to a life worth living. It can be argued that patients on dialyses do not live a life worth living because of their diminished quality of life. ${ }^{7}$ If more people have access to organs, fewer people will need dialysis and therefore fewer people's right to life will be infringed. The right to dignity is also applicable as it goes hand in hand with the right to life. ${ }^{8}$ It can also be argued that people on dialysis do not live a dignified life because of their restrictions.

The next section that should be noted is section 12(2)(b) of the Constitution. This section sets out that everyone has the right to bodily and psychological integrity which includes the right to security in and control over their body. ${ }^{9}$ Organ donations give effect to this right in the sense that one practices autonomy when making the choice to donate or not. I will, however, later in this article discuss why the full effect is not given to this right, where after I will set out how the implementation of organ trading will give effect to this right.

Section 27 of the Constitution provides everyone with the right to access to health care. ${ }^{10}$ Section $27(2)$ places a duty on the state to

$5 \quad M$ Freedman 'Shocking: Less than $0.2 \%$ of SA are Organ Donors' 18 April 2017 https://www.health24.com/Medical/Heart/Heart-transplants/shocking-lessthan-02-of-sa-are-organ-donors-20170418 (accessed 22 March 2018).

6 Section 11 the Constitution of the Republic of South Africa,1996.

7 B Venter 'A selection of constitutional perspective on human kidney sales' (2013) Potchefstroom Electronic Law Journal at 362.

8 Section 10 the Constitution (n 6).

9 Section 12(2)(b) the Constitution (n 6).

10 Section 27 the Constitution (n 6). 
take legislative and other measures to give effect to this right, which lead to the enactment of the National Health Act. ${ }^{11}$ This section will also be discussed in more depth later in this article when I constitutionally justify the legalisation or organ trading.

\subsection{The National Health Act}

In South Africa, we follow an 'opting-in' system regarding organ donations. ${ }^{12}$ This means that people must indicate that they want to donate organs on a voluntary basis. ${ }^{13}$ South Africa, the United Kingdom and the United States of America are some of the countries that follow the 'opting-in' system. ${ }^{14}$ The donation is seen as 'the gift of life' and remuneration for the organ is strictly prohibited by legislation. In the past, organ and tissue donations were regulated by the Human Tissue Act, ${ }^{15}$ this Act has, however, been repealed by the National Health Act. Chapter 8 of the National Health Act now regulates the use of organs, blood, gametes, blood products and tissue. ${ }^{16}$

Section 60 of the National Health Act is very clear regarding remuneration for the importation, acquisition or supply of tissue, blood, blood products or gametes. ${ }^{17}$ Section 60(4) expressly states that payment for the above mentioned donations is prohibited, except for reasonable costs incurred to make such donation possible. ${ }^{18}$ Section $60(5)$ states that the legal sanction for the infringement of section 60(4) is either a fine or imprisonment for up to 5 years or both. This penalty is because the Act regards it as an offence for a donor to receive a financial reward for such donation (except for reimbursing their reasonable costs) as well as the sale or trade in tissue, gametes, blood or blood products except as provided for in the Act. 19 The reasonable cost incurred includes the payment of the medical practitioner who carries out the procedure, as section 60 (3) allows for the payment of a health care provider for the professional service rendered by him or her. ${ }^{20}$

To better understand the procedure regarding organ transplants in South Africa, a distinction must be drawn between living and deceased donors. It must also be noted that the kidney and a part of

11 Section 27(2) the Constitution (n 6).

12 M Slabbert 'Combat organ trafficking - reward the donor or regulate sales?' (2008) Koers at 77.

13 M Slabbert 'Establishing a market for Human organs in South Africa part 1: $a$ proposal' (2007) Obiter at 45.

14 Venter (n 7) 353.

15 Human Tissue Act 65 of 1983.

16 National Health Act 61 of 2003 (hereafter NHA).

17 NHA (n 16) sec 60.

18 NHA (n 16) sec 60(4).

19 NHA (n 16) sec 60(5).

20 NHA (n 16) section 60(3). 
the liver lobe are the only organs that can be donated from a living donor. ${ }^{21}$ According to section 55 of the National Health Act, living donor donations are made according to the will of the living person and the living donor must give written consent for the donation prior to the donation. ${ }^{22}$ On the other hand, dead donor allocation will occur in accordance with what the deceased stipulated in his or her will or made clear orally in a statement in front of two competent witnesses. ${ }^{23}$ Donations of human bodies and tissue of deceased persons may also be donated in terms of a written document signed by two competent witnesses. An intended donation must be stipulated in the will, document or statement, otherwise, it will render the donation null and void. ${ }^{24}$

When it is not clear what the deceased's stance was on the donation of human tissue or organs, consent can be given on behalf of the deceased. Section 62(2) of the National Health Act provides us with the persons who may consent on behalf of the deceased: the spouse, partner, major child, parent, guardian, major brother or major sister of that person, in the specific order mentioned, may donate the deceased's body. ${ }^{25}$ When one of the aforementioned people cannot be located, the Director General has the right to donate the body and human tissue of the deceased. However, this may only occur if all the prescribed steps have been taken to locate the aforementioned persons. ${ }^{26}$

Donations from living persons are only allowed if they are related by blood to the patient in need of a transplant, or if the donor is the patient's spouse or partner. If this is not the case and the donor is not related or married to the patient in need of a transplant, a further procedure must be followed. An application must be made to the Department of Health, to get the written consent from the Minister for the transplant to take place. ${ }^{27}$ The Minister's consent is also required for an organ to be transplanted in a person who is not a South African resident. ${ }^{28}$ These stipulations have been made to try and curb the number of illegal transplants (or transplants in exchange for remuneration) that take place. It is easy to understand why a mother would want to donate a kidney to her sick child, but when it is a stranger wanting to donate, without any benefit to them whatsoever, a reasonable suspicion is raised.

21 M Slabbert, FD Mnyongani \& N Goolam 'Law, religion and organ transplants' (2011) Koers at 262.

22 NHA (n 16) sec 55.

23 NHA (n 16) sec 62(1).

24 NHA (n 16) sec 62(1)(c).

25 NHA (n 16) sec 62(2).

26 NHA (n 16) sec 62(3).

27 Slabbert (n 12) 87.

28 NHA (n 16) section 61(3). 
It is also noteworthy to distinguish between organ allocation in the public sector and the private sector. Netcare, the biggest private hospital group regarding transplants in South Africa, handles the process of organ donations. They have a specific procedure they follow when dealing with the allocation of organs. Firstly, the patient is diagnosed. This involves it becoming evident that the patient will need a transplant because of one of their organs not functioning properly anymore. The patient is then referred to a certain transplant unit where the patient will meet their transplant coordinator and discuss the way forward. The patient will only be accepted onto the transplant list after being assessed and it is established that the patient is healthy enough to be eligible for receiving a specific organ. ${ }^{29}$ Organ allocation is regarded as less 'formal' in the public sector since the referrals are based on the doctor's opinion of the patient. Some of the things the doctor will consider include the location of the recipient, his health, he must have a prospect of living at least two more years after the transplant, he must be younger than 60 years, if diabetic younger than 50 years and he may not have certain illnesses such as HIV or hepatitis. ${ }^{30}$ Section 65 of the Nation Health Act also provides for the revocation of the donation. ${ }^{31}$ This is to protect the donor, should he change his mind.

\subsection{Criticism}

This system of organ procurement may seem nice on paper: It is regulated by legislation, there are certain procedures and guidelines that need to be followed, the donor is protected and best of all, the donations are made on a voluntary basis, so there seems to be no need to change it. This system is, however, a failing system.

It is relevant to refer to the statistics given in the introduction again. These statistics are already an indication that the current system is not working. The fact at hand is that the statistics clearly indicate a shortage of transplantable organs, but it cannot precisely indicate just how big of a problem we are facing. This is especially true regarding the shortage for kidneys. There is no national list with the number of people on dialysis, nor is there a national waiting list, therefore these statistics can only be used as an indication. ${ }^{32}$ This raises a big concern, surely organ transplants and the number of people waiting for a transplant should be better regulated? Regardless of which system is being used to procure organs, the system should be better regulated.

29 M Slabbert 'One heart - two patients: Who gets the donor organ' (2009) Stellenbosch Law Review at 135.

30 Slabbert (n 29) 136.

31 NHA (n 16) sec 65.

32 Slabbert (n 13) 64. 
The demand for organs needed for transplantation increases daily. The supply can simply not meet the demand. ${ }^{33}$ Slabbert recognises the importance of finding a new system. She states that while countries are busy looking into new ways to motivate more people to become organ donors, the shortage of organs causes the black market to thrive. ${ }^{34}$ I agree with this point of view, as it makes sense that when the demand for organs cannot be met desperate, terminally ill patients will start looking at alternative options such as the black market.

It can be argued that the legislation regulating the current system is inadequate. This brings me back to section 60(4) of the National Health Act. As mentioned above this section makes provision for the donor to be reimbursed for reasonable costs incurred, regarding the donation. What exactly includes 'reasonable costs'? Reasonable costs are not described in the National Health Act's regulations, nor is there any mention made of it in the definition section of the Act. ${ }^{35}$ This also raises the question of who will determine if the fees paid was reasonable should an investigation rise? This leaves the door open for the price of the organ being included within the 'reasonable costs' ${ }^{36}$

The current legislation does not give enough consideration to the individual's autonomy. Even if there is a clear indication that a person wants to be an organ donor, once he is deceased, his decision can easily be overruled by that of his family. There might be a sticker in his identification document indicating that he is a registered organ donor, which reflects his wish to donate, but if the family does not give their consent, his organs will not be donated. ${ }^{37}$ Another issue regarding this is the fact that the health care providers are under no obligation to ask the family that the organs be donated. ${ }^{38}$ It is a very sensitive topic to approach the family in their time of grief and it is understandable that it might be daunting for the practitioner to raise this topic with the family, but by simply ignoring it and making the decision not to ask the family about it, the chance is missed to potentially save the life of 7 more people. ${ }^{39}$

The current system does not promote equality. Section 9(1) of the Constitution states that everyone has the right to equal benefit and protection from the law. ${ }^{40}$ Since there are not enough organs available to meet the demand, not everyone is getting equal benefit and protection from the law, this is thus an infringement of section

39 Organ Donor Fund https: //www.odf.org.za/ (accessed 4 April 2018).

40 Section 9 the Constitution of $(n 6)$. 
9(1) of the Constitution. ${ }^{41}$ The way the current system of organ allocation works infringes the equality principle: One organ goes to the private sector and one goes to the public sector. Prima facie this seems fair, however, only $27.7 \%$ of the population make use of the private sector. The allocation of organs between the private and public sector is thus greatly uneven and not in line with the principle of equality. ${ }^{42}$ Another indication of the unequal distribution of resources is the fact that only 8 out of the 18 hospitals in South Africa, that perform transplants, are state hospitals and the remaining 10 are private hospitals, although there are more patients that make use of state hospitals. ${ }^{43}$

\section{The different organ procurement systems worldwide:}

\subsection{Opting-out}

This system is also known as presumed consent and is the opposite of the opting-in system. In this system, everyone is regarded as an organ donor upon death unless an individual chooses to 'opt-out' by indicating that he or she does not wish to be an organ donor. ${ }^{44}$ This system of organ procurement is used in countries such as France and Belgium which entails a National register to be kept with the names of all the people who do not want to be organ donors. This list is readily available to all hospital staff to check once a person is declared brain dead and thus a suitable donor. ${ }^{45}$

The problem with this presumed consent system is just that. It is presumed. This might be seen in a negative light with the public as it creates the idea that the state has the right to take and distribute our organs as they seem fit. Once the public loses confidence in the transplantation system it will lead to a decrease of available organs. ${ }^{46}$ There are some ethical concerns regarding this system, especially because the consent is presumed. Administrative issues or flaws in the system can lead to people's autonomy not being respected. The following example can be used to illustrate this point: If South Africa changes its organ procurement system to that of opting out, to make

41 D Labuschagne \& PA Carstens 'The Constitutional influence on organ transplants with specific reference to organ procurement' (2014) Potchefstroom Electronic Law Journal at 218.

42 Labuschagne \& Carstens (n 41) 219.

43 K Hawkins 'Organ donation in South Africa: Opt-in, opt-out or mandated choice?' LLM thesis, University of Witwatersrand, 2017 at 26.

44 Slabbert (n 13) 45.

45 Slabbert (n 13) 46.

46 Hawkins (n 43) 28. 
the transition will take time, this time gap will lead to people's organs being removed without them having 'opted-out' yet.

To change the system will require that everyone must understand the system and know of their right to opt-out. Access to information is thus an imperative part of this system. This is not a viable option in South Africa as the diversity in language, the limitation on literacy and barriers regarding access to information makes it nearly impossible to ensure that informed consent is achieved. ${ }^{47}$ This system will also lead to inequality as the poor and uneducated will have a greater chance of not having their autonomy respected than that of the educated, who will be aware of their option to opt out. ${ }^{48}$

\subsection{Required request}

This system is also known as routine enquiry and entails that patients are asked to consider donating their organs once admitted to hospital. The hospital staff consults with the patient or his next- of- kin and asks them to consider donating their organs should they be near death or already deceased. It is merely a request to consider and the patient or next-of-kin is under no obligation to give an answer. ${ }^{49}$

Slabbert notes that to change a system of organ procurement to that of required request seems futile as none of the countries using this system have sufficient organs for transplantation. ${ }^{50}$ This system will also put more strain on the national health budget as resources such as national databases and trained personnel will be required. Not everyone dies in a hospital or is even admitted to hospital in their lifetime, not enough citizens will be reached to supply in the need for organs. ${ }^{51}$

\subsection{Mandated consent}

This system makes use of a platform in which it requires citizens to make a choice regarding organ donations. There will be a section regarding organ donations on the paperwork when dealing with various government-run procedures such as applying for a driver's licence or doing a tax return. It gives people 3 options: Organ donor, non-organ donor or family decision upon death. ${ }^{52}$ This system makes

47 Hawkins (n 43) 30.

48 Slabbert (n 13) 47.

49 EJ Fourie "An analysis of the doctrine of presumed consent and the principles of required response and required request in organ procurement' LLM thesis, University of Pretoria, 2005 at 100.

50 Slabbert (n 13) 45.

51 D Labuschagne 'An analysis of organ transplantation in South Africa with specific reference to organ procurement' LLM thesis, University of Pretoria, 2013 at 57.

52 Hawkins (n 43) 2. 
people more aware of organ donations as it gets people talking about donations.

Strict regulations would have to be put in place for this system to work. It should make provision for people to be able to later change their mind to ensure that their autonomy is respected. Without this understanding, informed consent cannot be given. ${ }^{53}$ The question of equality will again be raised with this type of system. Many of the poor, uneducated people would not partake in government procedures such as tax returns or applying for a driver's license. They would be excluded and thus be denied the chance to be an organ donor. This is also not a viable option for South Africa, not only because of the point just raised, but also because of the high numbers of illiteracy. Many people cannot read or might not understand the procedure as explained on paper, it would be better for someone to explain it to them in person. ${ }^{4}$

It has been argued that the term mandated consent is confusing as it seems like consent is forced, where it is rather that the choice is mandated but giving consent is not. This can also lead people to lose trust in transplant systems, discouraging them to choose to be a donor. Mandated choice might be a more suitable term for this system. ${ }^{55}$

\subsection{Xeno-transplantation}

Xeno-transplantation refers to a system where animal organs are procured to be transplanted into human bodies. Medical research is inadequate for this option to be used as a procurement system. ${ }^{56} \mathrm{It}$ must also be noted that South Africa is a third world country which results in the fact that it would take much longer for us to ascertain the resources to reach a point where this is a possibility for a procurement system.

\subsection{Organ donations by prisoners}

Until as recent as 2013 this method of organ procurement was used in China and has been a very controversial method for the procurement of organs. ${ }^{57}$ Prisoners' organs are procured in one of two ways: Either by making a deal with the prisoner, his organs in exchange for a decrease in his prison sentence or by harvesting the deceased 
prisoners' organs before the bodies are released to family members. ${ }^{58}$ It is understandable why this system has provoked controversy.

One of the arguments against this system is that it is exclusive. Only the prisoners get the option of having a reward for donating their organs (reduced sentence) while other people who also make the choice to donate their organs get no reward. ${ }^{59}$ I agree with this argument as it seems very unfair that bona fide people get no reward for their goodwill, while prisoners are rewarded for their choice. If a certain system of organ procurement is put in place it should apply equally to all people.

This kind of system will also be very difficult to regulate. If the prisoner gets a lesser sentence because of the agreement that he will become a cadaveric donor, and he then at a later stage decides not to donate or his organs are not fit for donation, the prisoner will then have gotten a lesser sentence in exchange for nothing. ${ }^{60}$ There is not a simple solution to this problem. One cannot simply say that they will not be allowed to change their mind at a later stage. Losing the right to revoke their decision is taking away their freedom of choice and bodily integrity. This system cannot be constitutionally justified.

\subsection{The sale of organs}

Iran is currently the only country in the world where it is legal to sell one's organs in return for financial remuneration. With this system in place, Iran has solved their shortage of transplantable kidneys. ${ }^{61}$ The matter in which it is regulated in Iran is as follows: There are no organ brokers, the organ transplant system is government funded and the government pays a fixed price for the organs received. ${ }^{62}$ This is a way to prevent exploitation from taking place. If there is no middleman charging people an exorbitant price for organs, with only a regulated fixed price in place, the entire system becomes more fair.

A non-profit government organisation registers buyers and sellers and then puts these sellers into contact with the patients. As far as the government is concerned, organs are not allowed to be sold privately. This is something that must be regulated very carefully otherwise exploitation will take place. The organ waiting list has been virtually eliminated, there is still, however, a waiting period of roughly one year before the procedure takes place. ${ }^{63}$ The waiting

58 Labuschagne (n 51) 66.

59 Labuschagne (n 51) 67.

60 Labuschagne (n 51) 65.

61 S Fry-Revere The kidney sellers: A journey of discovery in Iran (2014) 204.

62 Labuschagne (n 51 above) 62.

63 Health24 'The dark world of internet kidney trafficking' https://www. health24.com/Medical/Kidney-and-bladder/News/The-dark-world-of-internetkidney- trafficking (accessed 3 January 2018). 
period is mostly due to ensure that everything goes well with the procedure. The buyers and sellers go for medical and psychological screening. Doctors in Iran have performed more than 30000 kidney transplants in this way since 1993. An organ is usually set for a fixed price of 4600 American Dollars. ${ }^{64}$

\section{Arguments for the legalisation of organ trading}

\subsection{It will decrease the organ shortage}

The fact that Iran basically does not have a waiting list for organs anymore is already an indication of my point that this system will decrease the organ shortage. ${ }^{65}$ If we look at other countries in the world, regardless of the procurement system they use, their supply cannot match the demand for organs.

To add a financial reward to the donation could encourage more people to become organ donors, ${ }^{66}$ which in return will decrease the shortage. Without any financial reward, people are not jumping at the chance to become living organ donors. It is a painful procedure that involves a lot of administration, the donor will have to take time off of work and most importantly, the costs are high. When you are the recipient, and lucky enough to be a member of a medical aid, the aid will pay for the operation and your stay in hospital. However, the medical aid will not provide for the costs incurred by the donor, such as the donor's hospital stay, medical expenses, traveling expenses and medication. ${ }^{67}$

In today's capitalist society where people are driven by greed and what they can take rather than what they can give, in my opinion, almost no person will go through the above for an absolute stranger without a reward. Yes, there is a reward in the form of the satisfaction you get from knowing you helped save a person's life, but sadly, in the world we live in, that simply will not be enough. More people might be willing to be organ donors after they have become deceased, as this will eliminate the above-mentioned burden to them. However, the number of living donors must be increased to combat the shortage of organs. ${ }^{68}$

There are several benefits when using live organ donors instead of cadaveric donors. Firstly, better planning can be done, a time can be discussed for the procedure that fits both the donor and recipient's

64 Labuschagne (n 51 above) 62.

65 A Haffejee 'Commerce in organs - an ethical dilemma' (2003) South African Medical Journal at 845.

66 Slabbert (n 15) 263.

67 Slabbert (n 15) 272.

68 Slabbert (n 23) 137. 
schedules best. There is more time to prepare for the procedure, which can play an essential part in the safety and success of the transplant. More time can be taken to perform medical and psychological screening on the donor, which can help detect any illnesses in the donor. ${ }^{69}$ Comparisons between the tissue of the donor and recipient tissue can also be done more precisely, which will decrease the chances of rejection after the transplant has taken place.

\subsection{It will combat organ trafficking}

If there is a demand for organs which cannot be met by our current system, there will be a black market. ${ }^{70}$ Desperate patients all over the world turn to the black market to buy organs, while people in desperate financial situations line up to provide these organs, at a price. People are concerned that the legalisation of organ trading will be exploitive, but what is currently taking place on the black market is exploitive. People that are in desperate financial need, will go as far as to sell their kidneys for only 1000 American Dollars, while the 'middleman' or organ broker will make all the profit. There is no regulation so there is not even a guarantee that they will get their money or that the operation will be safe. ${ }^{71}$

A few years ago, a huge scandal was unveiled that took place in South Africa. It was revealed that between the years 2001 and 2003, 109 illegal kidney transplants took place at the St Augustine's Hospital in Durban. 5 of these illegal transplants were conducted by removing kidneys from minors. The St Augustine Hospital forms part of the Netcare group, the biggest private hospital group in charge of organ transplants in South Africa. At first, it was an Israeli organ broker syndicate that brought Israelis, who are willing to buy organs, to South Africa. This syndicate initially bought the organs from other Israelis for 20000 American Dollars on average, after which the recipient had paid the syndicate an average of 120000 American Dollars. The syndicate then moved on to sellers from Romania and Brazil after realising that they would sell their kidneys for far less and paid these people only on average about 6000 American Dollars. Hospital staff and doctors at this hospital were involved in the scandal which lead to the Netcare group, having to as an admission of guilt, pay a fine of nearly R4 million because of their involvement. According to one of the surgeons prosecuted, the illegal operations that took place were

71 Health24 'The dark world of internet kidney trafficking' https://www. health24.com/Medical/Kidney-and-bladder/News/The-dark-world-of-internetkidney- trafficking-20150225 (accessed 3 January 2018). 
only a small part of a further 220 illegal kidney transplants that took place countrywide. ${ }^{72}$

If organ trading is legalised it will combat organ trafficking. Once you have a strictly regulated market, it will cut out middlemen whose sole purpose is to make a profit. ${ }^{73}$ If you take out the middlemen and the main agenda is not profit anymore but saving lives and helping people in need of money, a different picture is painted. If there is no middleman and the demand is not so high anymore, because of an increase in the supply, the organs will not be sold at $r$ unaffordable prices anymore. If there is not so much money at stake, the temptation to traffic people for their organs become less. If a syndicate knows he can get 120000 American Dollars or even more on the black market for an organ, people will be trafficked, but if organs become freely available at affordable prices, there will be no need for a black market. ${ }^{74}$ A person who needs an organ would rather pay a fixed, government regulated price, which they know will be a wellplanned and safe procedure, rather than turn to the black market for an overpriced organ with absolutely no protection or guarantees. Organ trafficking takes place because of the existence of a black market. A black market only exists because organ trading is illegal.

\subsection{It is fair-All parties will be rewarded}

With the current system in place, only the medical staff and the recipient is rewarded. The medical staff that is involved with all the procedures leading up to and during the transplant is remunerated for their services, as they should be, and the recipient receives an organ, which is a wonderful second chance at life. Why not give the donor a reward too since they make a big sacrifice and are, after all, a significant part of the process?

The National Health Act already provides for the reimbursement of reasonable costs incurred by the donor, we might just as well go a step further and reward them for their choice. ${ }^{75}$ All the parties will benefit and be protected in a regulated environment. ${ }^{76}$ When the sale of organs is not regulated, as they aren't when being sold on the black market, it is a very dangerous situation. The recipient has no guarantee that the correct precautionary measures have been taken before the transplant or if a safe, matched organ is being used. There might be rejection as soon as the transplant is completed and the

72 Health24 'The dark world of internet kidney trafficking' https://www. health24.com/Medical/Kidney-and-bladder/News/The-dark-world-of-internetkidney- trafficking-20150225 (accessed 3 January 2018).

73 Khoza (n 4) 47.

74 A kidney that was auctioned on eBay in 1999 hit the cost of $\$ 5.7$ million before the sale was stopped.

75 Slabbert (n 7) 91.

76 Slabbert (n 15) 271. 
people responsible will be gone with the recipient's money. It is also just as risky for the organ seller, as he also has no guarantees and might never see the money he was promised. It might be easy to say they should simply not turn to the black market for help, but when people are in such a desperate situation it seems like the solution. If people are going to turn to the black market, why not bring the system in place? At least all parties involved will be protected and get the benefit they need. ${ }^{77}$

\subsection{It can be constitutionally justified}

Section 2 of the Constitution states that the Constitution is supreme and any law inconsistent with the Constitution is invalid. ${ }^{78}$ We must thus test whether organ trading is in line with the Constitution and can be constitutionally justified.

We have already determined that the current system is not in line with the equality clause, as set out in section 9 of the Constitution. A concern raised by many is that the legalisation of organ trading would be unequal because of the big division between rich and poor. ${ }^{79}$ Slabbert believes that the ability to pay should never be a criterion for whether a person should have access to an organ or not. She states that access to organs should be made more equal even if that involves more state involvement. ${ }^{80}$ The implementation of the organ trading will require exactly that, more state involvement. The state will be responsible for the payment of organs, which poor people cannot afford, while medical aids will be responsible for the payment of organs for its members. Later in this article, I will discuss in detail how this system should be implemented to be in line with equality. Currently, there is not enough organs available and this causes inequality. If there become more organs available, more people will have access to these organs which will promote equality.

The right to human dignity and the right to life are complementary, they go hand-in-hand as these two rights should be valued above all other rights in the Constitution. ${ }^{81}$ Once a person is in a situation of poor health it decreases their human dignity and right to life. ${ }^{82}$ The right to life includes the full enjoyment of life and people who are sick and on dialysis are not living a full, dignified life because of their restrictions. ${ }^{83}$ The right to life and dignity of people who are in need of a transplant is being infringed. The ideal solution

78 Section 2 the 845.

78 Section 2 the Constitution (n 6).

79 http://www.debate.org/opinions/should-the-sale-of-human-organs-be-legal (accessed 23 February 2018).

80 Slabbert (n 23) 129.

81 Labuschagne and Carstens (n 36) 219.

82 Venter (n9) 368.

83 Venter (n 9) 362. 
for them is to get a transplant and the legalisation of organ trading can provide for this. If more organs are available, more people will have access to these organs and more lives will be saved which is in line with the promotion of life. ${ }^{84}$

Section 12(2)(b) of the Constitution reads: 'Everyone has the right to bodily and psychological integrity, which includes the right to security in and control over their body. ${ }^{85}$ The control over one's body implies that we should have a say in what happens to our body and have the choice of what we want to do with our bodies. It is this very argument that allows women to legally terminate their pregnancies. ${ }^{86}$ Venter states that if one can end a life because of this right in the Constitution, then surely one should be able to save a life because of the same right. ${ }^{87}$ The legalisation of organ trading is in line with respecting the autonomy of people; it does not compel them to do anything while still giving them the option. ${ }^{88}$ It provides freedom of choice over our bodies. Allowing the sale of organs will be a recognition of people's rights as set out by section 12(2)(b) of the Constitution. 89

Another important section of the Constitution to look at is section 27 as it provides for health care. Section 27(1)(a) provides that everyone has the right to access to health care. ${ }^{90}$ Two hospitals in Gauteng were willing to provide statistics surrounding their dialysis units. At these two hospitals alone, they show away approximately 500 patients each on a monthly basis. That is a 1000 people who go home every month without the urgent medical care they need. ${ }^{11}$ These people do not have access to health care, making it a direct infringement of their constitutional right. Section 27(2) further imposes a duty on the state to take reasonable legislative measures, within its available resources, to give effect to the rights set out by section $27(1) .{ }^{92}$ This section of the Constitution was dealt with in detail in the case of Soobramoney $v$ Minister of Health, KwaZuluNatal. ${ }^{93}$

The Soobramoney case dealt with a person who needed a kidney transplant and who was on dialysis at a private hospital. His funds,

Slabbert (n 15) 263.

Section 12 the Constitution (n 6).

Christian Lawyers Association of South Africa v Minister of Health 19984 SA 1113 (T) par 32.

Venter (n 9) 375.

Slabbert ( $n$ 7) 94

Slabbert (n 8) 55.

Section 27 the Constitution (n 6).

Clairwyn van der Merwe 'SA's shortage of organs for transplant affects thousands' 3 August 2017 https://www.unisa.ac.za/sites/corporate/default/Research-\&Innovation/News-\&-events/Articles/SA\%27s-shortage-of-organs-for-transplantaffects-thousands (Accessed 4 April 2018).

Section 27(1) the Constitution (n 6). 
however, ran out and he had to depend on public health care. The state hospital, however, showed him away as he did not meet the criteria to receive renal dialysis. Mr Soobramoney was 41 years old and was also suffering from heart disease, vascular disease and was a diabetic. Mr Soobramoney's health issues meant that he was not eligible for a transplant and the hospital only provided dialysis for patients who were eligible for a transplant, because of the shortage of dialysis machines. He made an urgent application, in terms of his right to life $^{94}$ and his right to receive emergency treatment, ${ }^{95}$ to a local division of the High Court for an order directing the Addington Hospital to provide him with ongoing dialysis and interdicting the respondent from refusing him admission to the renal unit of the hospital. The application was dismissed. The court held that section 27(3) is not applicable as his case was not one of emergency, but that his condition was ongoing. Mr Soobramoney could also not rely on his right entrenched in section 27(1)(a) of the Constitution as access to health care should only be provided within the 'available resources' of the state. As there was a shortage of dialysis machines in the state hospital, it was not in the state's available resources to provide the treatment. ${ }^{96}$

Venter asks the question, that when a resource has been limited for a number of years, does it not impose a duty on the state to find an alternative that could relieve the need? ${ }^{97}$ This is what section $27(2)$ does. Many people are currently not getting the dialysis they need, their access to health is thus infringed upon. This results in the state having to take reasonable legislative measures, within its available resources, to give effect to the rights set out by section 27(1). Some might argue that the legislative measures involving the legalisation of organ trading is not possible as it is not within the available resources of the State. This is, however, not a valid argument as the legalisation of organ trading will be more cost effective to the government. At this stage, the government must pay for the dialysis of state patients, which is set at approximately R200 000 per annum, per patient. ${ }^{98}$ It would make more sense financially to rather pay a once-off amount for an organ transplant at a fixed, regulated price.

94 Section 11 the Constitution (n 6).

95 Section 27(3) the Constitution (n 6).

96 Soobramoney (n 93) par 53.

97 Venter (n 9) 388.

98 Venter (n 9) 362. 


\section{Addressing the arguments against the legalisation of organ trading}

\subsection{Selling organs is unethical}

Friedman and Friedman responded to this argument by asking "just what is so ethically wrong?' They compare it to the selling of ova and sperm, transactions which are legal in the United States, and ask why it is worse to sell one's organs. They raise the point, that in fact, it should be more ethically wrong to sell ova and sperm as these cells can create new life. ${ }^{99}$

There is also an argument that it is unethical because people will put themselves through a risky operation just because of their financial situation. A study done in the United States of America showed that the risks for a living donor are slight, as only 0,03 percent of kidney donors died in a four-year cycle after the donation. ${ }^{100}$ This can be compared to the same amount of risk as driving a car for 16 miles every day. ${ }^{101}$ The same medical tests and procedures will still have to be followed to ensure the safety of both the donor and the recipient, the fact that remuneration is given for the organ has nothing to do with the risk involved in the operation. ${ }^{102}$

Some are also against the idea of selling one's organs because it is irreversible if they regret their decision once the transplant has been completed, there is nothing that can be done. This is again, why I emphasise how important it is to establish a well-regulated market. Some guidelines can be put in place to prevent this from taking place, such as setting a certain time as a 'cooling-off' period between the time the person decides to sell their organs and the actual transplant taking place. An age restriction should also be imposed, for instance, no-one under the age of 25 can sell their organs. ${ }^{103}$

\subsection{Body parts cannot be commodified}

The definition of a thing in a South African law context is as follows: 'It is a corporeal object that is external to persons and which is, as an independent entity, subject to juridical control by a legal subject, to whom it is useful and of value. ${ }^{104}$ Specific reference must be made

99 Slabbert 'Ethics, justice and the sale of kidneys for transplantation purposes' (2010) Potchefstroom Electronic Law Journal at 99.

100 Slabbert (n 93) 94.

101 Slabbert (n 7) 57.

102 Slabbert (n 7) 93.

103 Slabbert (n 7) 58.

104 Mostert $\mathrm{H}$ \& Pope A (eds) The principles of the law of property in South Africa 2010 at 235. 
to 'external to persons' which indicates that organs are not regarded as things and can therefore not be sold as it is a thing incapable of being owned. A human is a subject who holds rights but cannot be the object of a right. ${ }^{105}$

If no one owns our body, who has a say in what happens to our bodies? It can be argued that the deceased's next-of-kin has property rights over the body since they can decide what happens to our organs after death. We do, however, have property rights in our bodies, since we have the choice to terminate a pregnancy as well as the fact that one can only consent to something being donated if you are the legal owner thereof. ${ }^{106}$ We can also stipulate in our will if we wish to be cremated, this is also exercising rights over our bodies. This indicates that the current position in law is wrong and the law should be amended to provide for property rights in our bodies and that body parts should be provided for in the definition of a thing. A thing was defined in a South African law context before the possibility of trading one's organs, it was not foreseeable that medical science would advance to this point where it is possible. ${ }^{107}$

Kant, who is a philosopher, stated that if you buy and sell organs you are giving human beings a market value, thus treating them as objects which is an infringement to their human dignity. ${ }^{108}$ This is, however, missing a crucial point, body parts are already being commodified by the existence of a black market, where desperate people are extorted into selling their organs at low prices, because of their dire situations. It is our bodies, we should have property rights over it and exercise control. Our body is our property, we may treat it as an object if we please to do so. The infringement of dignity takes place when we treat other people's bodies as objects. ${ }^{109}$ By allowing the sale of organs, you are simply providing them with the choice to exercise personal autonomy.

\subsection{It will be exploitive}

There is already exploitation taking place with the current system, especially as the black market is thriving, feeding off of the vulnerability of the poor. To regulate the sale of organs might do the opposite of causing exploitation and reduce the current exploitation taking place. ${ }^{110}$ If people are going to turn to the black market because the current system is failing them, why not regulate the

105 Slabbert (n 7) 53.

106 Slabbert (n 7) 54.

107 Slabbert "“This is my kidney, I can do what I want with it" - property rights and ownership of human organs' (2009) Obiter at 517.

108 Slabbert ( $\mathrm{n} 7) 58$.

109 Slabbert (n 7) 59.

110 Slabbert (n 8) 91 . 
market in a way that all parties are protected? ${ }^{111}$ In this manner, all the parties will benefit, not as in the current system where the donor does not receive anything. To expect the donor to go through all the trouble, costs and pain of a transplant without allowing remuneration is exploiting the donor. ${ }^{112}$ In the next chapter, I will discuss in detail how this system should be implemented, to avoid exploitation, benefit all parties and promote equality.

\section{Recommendations}

\subsection{Differences from the Iran system}

As discussed earlier, it is legal to trade organs in Iran. I would suggest a very similar system with some differences. I agree that there should not be any organ brokers, no private organs can be sold and that the transplant system should be government funded. In Iran, however, a non-profit organisation registers buyers and sellers and then puts them in contact with each other. I recommend that this is implemented differently in South Africa. The patient and the donor still have a right to privacy and their confidentiality should be respected. This will also ensure that there is not more money paid under the table between the parties. If the parties do not know each other and work independently with the established government body, they will have to abide by the fixed price, as regulated by legislation.

This brings me to my next point; a non-profit organ procurement organisation will have to be established. They will oversee registering all the buyers and sellers and will be the only organisation in South Africa that regulates the buying and selling of organs. It will be much easier to investigate the conduct of one organisation than to keep track of different, independent organisations.

\subsection{The amendment of legislation}

Section 60 of the National Health Act should be repealed. As mentioned in the previous chapter, the definition of a thing in the property law context will have to be amended. New legislation should be enacted to provide for the trade in organs and how it should be regulated. This legislation should also determine a fixed price for organs, which should be amended annually in accordance with inflation. Another very important aspect is that a national donor list, as well as a national waiting list, should be created. These lists should also contain the medical information of the parties to ensure that

111 Khoza (n 4) 47.

112 A Garwood-Gowers 'Living donor organ transplantation: Key legal and ethical issues’ (1999) 192. 
quicker matches can be made. This is an imperative part of making sure that this system is regulated carefully.

\subsection{How the system will work in regards with living donors}

All prospective buyers and sellers should register at the organ's procurement organisation. There should be various offices of this organisation nationwide to provide for equal access. The organisation should send the person for medical and psychological screening. The process will be explained in detail to both the buyer and seller to ensure informed consent can be given. Immunological tests will then be performed to match organs of sellers and recipients. Once there is a match, the organisation will inform the buyers and seller of the match, without making clear the identity of either party. The buyer will then pay the fixed amount over to the organisation. This money will stay in a trust account until the operation has been completed.

Once the operation is completed, the money will be paid into the account of the seller. The seller gets the full amount of money regardless of whether the buyer's body receives or rejects the organ. If the buyer experiences rejection after the transplant and the doctors cannot reverse it, he, unfortunately, will not receive the money back. The risk of buying the organ is that of the buyer. This is something that should be explained to the buyer before the procedure. There should be a 'cooling-off' period of 6 months between the date the sale is concluded and the date on which the actual transplant takes place. ${ }^{113}$ This is to ensure that both parties have enough time to change their mind about the procedure, should they want to.

\subsection{How the system will work with deceased donors}

It seems the most popular option to regulate these sales is by means of a future contract. The contract will have to fulfil all the normal contractual requirements and will be concluded while the seller is still alive. The contract will be subject to a suspensive condition where the contract will only be enforceable once the seller is deceased. The money will then form part of the deceased's estate. ${ }^{114}$ This will also be controlled by the organ procurement organisation as the contract will be concluded between the seller and the organisation. While the seller is still alive he will also be accepted to go for medical and psychological screening. There will also have to be a provision in the contract stating that if a person commits suicide they are automatically disqualified from the program and the contract 
becomes void. This is to prevent people from committing suicide with the intention to sell their organs to provide for their family. Even with this provision, which will disqualify some people from selling their organs, I believe this system will still be successful in providing enough transplantable organs.

\section{Conclusion}

The purpose of this article was to determine whether the implementation of organ trading as a procurement system would be a viable option for South Africa. I critically analysed our current system and established that it is a failing system. Thereafter, I considered different procurement systems and analysed whether they can successfully be applied in South Africa. I considered all the aspects, positive and negative, surrounding the legalisation of organ trading. After all my considerations I conclude that the legalisation of organ trading is not only the most viable option for South Africa but also our only hope in procuring enough organs. 